\title{
KONSEP KESANTUNAN DALAM PEMBELAJARAN PENERJEMAHAN BAGI MAHASISWA PENDIDIKAN BAHASA INGGRIS
}

\author{
Sumardiono dan Ulupi Sitoresmi \\ Program Studi Pendidikan Bahasa Inggris, Universitas Slamet Riyadi \\ Email: sumardionozy@gmail.com
}

\begin{abstract}
Abstrak
Tujuan dari penelitian ini adalah untuk menggambarkan bagaimana strategi kesantunan digunakan dalam percakapan dalam buku Intermediate Javanese dan terjemahannya dan pentingnya strategi tersebut digunakan sebagai materi di kelas penerjemahan. Terdapat dua puluh dua data yang terdapat dalam empat percakapan. Pada tahap pertama, peneliti mengidentifikasi ujaran yang mengandung strategi kesantunan pada percakapan dalam buku Intermediate Javanese. Ujaran yang mengandung strategi kesantunan diklasifikasikan berdasarkan strategi kesantunan yang diterapkan. Pada tahap analisis, ujaran dianalisis alasan penggunaan strategi kesantunan tertentu. Berikutnya, strategi kesantunan yang diterapkan pada bahasa sumber dibandingkan dengan strategi kesantunan yang diterapkan pada bahasa sasaran. Berdasar analisis, ditarik kesimpulan bahwa; ada tiga strategi kesantunan yang diterapkan pada percakapan; strategi kesantunanyang diterapkan pada bahasa sumber sebagian besar diterapkan sama dengan pada bahasa sasaran. Hanya sebagian kecil terjadi pergeseran strategi kesantunan.Temuan tersebut digunakan sebagai model text bagi mahasiswa pada saat menerjemahkan teks berbahasa Jawa ke dalam Bahasa Inggris.Memahami konsep kesantunan penting tidak saja untuk menghasilkan terjemahan yang berkualitas namun juga sebagai pendidikan karakter bagi mahasiswa.
\end{abstract}

Kata kunci: Kesantunan, Penerjemahan, Pembelajaran Bahasa

\section{POLITENESS STRATEGY IN TRANSLATION LEARNING FOR ENGLISH EDUCATION STUDENTS}

\author{
Sumardiono and Ulupi Sitoresmi \\ English Education Department of Universitas Slamet Riyadi \\ Email:sumardionozy@gmail.com
}

\begin{abstract}
The purpose of this study was to find out what and how politeness strategies wereused in the conversation in Intermediate Javanese and its translation and how importance is the strategy to apply in translation classes. There are twenty two data gained in four conversations. First, the researcher identifled the utterance that contains politeness strategy in the conversation of Intermediate Javanese, the utterances which contained politeness strategy were classified based on the politeness strategy applied. In the analysis the utterances wereanalyzed why the speaker used certain strategy. The second, the strategy applied used in Javanese version were compared with the conversation of the English version. Some conclusions were drawn from this analysis; there were three strategies which wereapplied in the conversation; the politeness strategies used in the Javanese version were mostly used in the English version, only small parts were shifted. Those findings were used as model textduring the translation practices from Javanese to English. The concept of politeness is fundamental not only to produce qualified translation but also to provide with character building.
\end{abstract}

Keywords: politeness, translation, english learning 


\section{PENDAHULUAN}

Manusia dalam berkomunikasi satu sama lain membutuhkan bahasa sebagai alatnya.Begitu pentingnya peranan bahasa ini sehingga bahasa tidak saja digunakan digunakan dalam konteks non formal namun juga dalam konteks formal di sekolah selama proses belajar mengajar berlangsung. Bahasa, baik itu Bahasa Indonesia, bahasa daerah, Bahasa Inggris, maupun bahasa asing lainnya dipelajari mulai dari tingkat dasar hingga perguruan tinggi. Berbagai metode digunakan dalam pembelajaran bahasa. Salah satu metode yang acapkali digunakan yaitu Grammar Translation Method (GTM). Metode ini dimaksudkan untuk membantu siswa membaca dan mengapresiasi karya sastra asing dengan cara menerjemahkan teks dari bahasa asing ke dalam bahasa ibu. (LarsenFreeman, Diane,2000). Metode ini menekankan pada penguasaan tata bahasa dan kosa kata bahasa target.

Berbicara tentang pembelajaran bahasa dan penguasaan bahasa tidak cukup hanya pada elemen tata bahasa dan kosa kata semata. Konsep kesantunan berbahasa perlu dibekalkan.Konsep ini dapat diajarkan misalnya di speaking class. Di jenjang perguruan tinggi khususnya mahasiswa program studi Pendidikan Bahasa Inggris UNISRI terdapat mata kuliah Translation.Agar mampu menghasilkan terjemahan yang berkualitas seorang penerjemah perlu menguasai beberapa kompetensi penerjemahan. Salah satu kompetensi yang dimaksud yaitu kompetensi budaya. Bahasa merupakan bagian dari budaya. Oleh sebab itu penerjemahan dari satu bahasa ke bahasa lain tidak bisa dilakukan tanpa pengetahuan yang memadai tentang budaya dan struktur bahasa tersebut. (Larson,1984). Pemahaman tentang konsep kesantunan merupakan bagian dari penguasaan kompetensi budaya. Mahasiswa perlu diberikan materi tentang konsep kesantuanan ini melalui contohcontoh penerjemahan teks berbahasa Jawa ke dalam Bahasa Inggris.

Penerjemahan pada dasarnya adalah proses pengalihan pesan dari bahasa sumber ke bahasa sasaran. Seperti yang dikatakan oleh Newmark (1995)Translation is rendering the meaning of a text into another language in a way that the author intended the text. Dalam proses pengalihan pesan ini banyakhal yang perlu dipertimbangkan karena proses peralihan pesan membutuhkan banyak pendukung disiplin ilmu lain untuk bisa mendapatkan pesan seperti yang dimaksud teks bahasa sumber.

Kesadaran penerjemah bahwa antara bahasa satu dan bahasa lainnya memiliki cara yang berbeda dalam mengemas makna akan sangat membantu dalam memahami bagaimana makna dibentuk dan bagaimana mengidentifikasi makna pada teks bahasa sumber. Pemahaman ini sangat bermanfaat dalam proses penerjemahan. 
Karena penerjemahan adalah prosesmentransfer pesan dari satu bahasa ke bahasa lain, penerjemahan bertindak sebagai jembatan antara satu bahasa dengan bahasa lain dan bahkan antara satu budaya dengan budaya lain. Dalam proses menjembatani dua bahasa dan dua budaya ini, diperlukan pemahaman yang menyeluruh tidak saja sistem gramatika dan leksikal dari bahasa sumber, namun juga hal-hal yang berkaitan dengan budaya bahasa tersebut. Fokus artikel ini yaitu menggambarkan bagaimana strategi kesantunan digunakan dalam percakapan dalam buku Intermediate Javanese dan terjemahannya dan pentingnya strategi tersebut digunakan sebagai materi di kelas penerjemahan

\section{KAJIAN TEORI}

\section{Penerjemahan dan Pragmatik}

Di dalam proses penerjemahan, pemahaman penerjemah tentang sistem kebahasaan yang bersifat struktur permukaan tidaklah cukup, karena pesan atau makna dari sebuah teks tidak sekedar terletak pada struktur permukaan melainkan ada sesuatu yang lebih dalam yang perlu dipahami. Seperti yang dikatakan Baker (1992) bahwa tidak ada korespondensi satusatu antara kata-kata dan elemen makna antara dua bahasa. Menerjemahkan hanya berdasarkan struktur permukaansebuah bahasa tentu akan berakibat fatal, apalagi menerjemahkan kata perkata. Penerjemahan kata-perkata akan menghasilkan terjemahan yang tidak akurat sekaligus tidak berterima.

Karena teks bahasa memiliki dua struktur sekaligus; struktur permukaan dan struktur dalam, pemahaman sebuah teks memerlukan proses interpretasi. Proses interpretasi tidak sekedar menghubungkan struktur permukaan dan struktur dalam. Lebih jauh, proses interpretasi membutuhkan konteks, sesuatu yang bersifat ekstra linguistik. Kontekslah yang akan membatasi interpretasi sebuah teks. Tanpa konteks interpretasi akan bersifat liar dan bahkan menghasilkan pemaknaan yang bersifat ambigu. Konteks meliputi konteks situasi dan konteks kultural. Dengan demikian, ketika menerjemahkan, seorang penerjemah harus mempertimbangkan dua konteks ini sekaligus. Konteks situasi meliputi siapa pembicara, siapa yang diajak bicara, dimana percakapan itu berlangsung dan tentang apakah permbicaraan tersebut. Karena penerjemahan pada dasarnya adalah mengalihkan pesan teks yang terikat konteks, maka proses interpretasi dengan melibatkan konteks adalah proses yang harus ada. Farwell dan Heimrich (2007) mengatakan bahwa teks hanya bisa didekati melalui proses interpretasi.

Berdasarkan penjelasan diatas bisa disimpulkan pagmatik memiliki sumbangan yang sangat penting di dalam proses penerjemahan. Pragmatik membahas teks tidak sekedar pada tataran permukaan tapi menukik ke dalam. Pragmatiks tidak 
hanya membedah makna pada tataran daya lokusi, daya yang ditimbulkan oleh sistem leksikal dan gramatikal sebuah kalimat atau ujaran melainkan daya yang timbul setelah teks berinteraksi dengan konteks, baik konteks situasi maupun konteks kultural.

\section{Konsep Kesantunan}

Menurut Levinson (1987) kesantunan adalah strategi yang dipakai pembicara untuk mencapai beberapa tujuan tertentu seperti menjaga hubungan yang harmonis. Kesantunan adalah usaha pembicara untuk membuat hubungan baik dengan mitra bicara sehingga komunikasi bisa berjalan lancar. Pada dasarnya, kesantunan adalah sebuah pelumas sosial untuk menjaga harmoni sehingga masing-masing pihak merasa diperlakukan secara pantas sesuai dengan kedudukan sosialnya.

Yule (1996) mengusulkan istilah "muka" dalam kaitan konsep kesantunan. Menurutnya, "muka" adalah citra diri publik seseorang. Sementara itu Brown dan Levinson (1987) memandang "muka" sebagai sesuatu yang diinvestasikan secar emosional, muka bisa hilang, bisa dijaga atau ditingkatkan, dan harus secara konstan hadir dalam sebuah percakapan. Berkaitan dengan "muka" ini, ada mukapositif dan muka negatif. Muka positif menurut Brown dan Levinson (1987) sebagai "the positive and consistent image people have for themselves, and desire for approval", sementara muka negatif sebagai "the basic claim to territories, personal preserves, and rights to non-distraction". Menurut Levinson (1987) ada empat jenis strategi kesantunan yang dijelaskan sebagai berikut.

Bald On Record. Strategi ini digunakan ketika seorang pembicara menginginkan tindakan mengancam wajah secara maksimal. Strategi kesantunan ini diterapkan pada orang orang dengan jarak sosial yang sangat dekat misalnya teman dekat dan keluarga dekat. Meskipun strategi ini bisa juga digunakan pada keadaan darurat.

Kesantunan Positif. Strategi ini berusaha menjaga muka positif lawan bicara. Muka positif menurut Yule (1996) adalah keinginan untuk diterima, disukai orang lain, dianggap sebagai anggota kelompok. Pada strategi ini, pembicara berusaha meminimalisasi jarak sosial dengan mitra bicara dengan mengekspresikakeramahan dan meminimalisasi tindakan mengancam muka.

Kesantunan Negatif. Kesantunana ini berfungsi untuk meminimalkan beban tindakan mengancam muka yang tak terhindarkan. Dalam strategi kesantunan ini, pembicara berusaha menjaga jarak sosial dengan mitra bicara.

Off Record. Strategi ini adalah strategi yang paling jarang ditemui 
dalam percakapan umum. Strategi ini diterapkan oleh pembicara dengan memberi kode kepada mitra tutur.

\section{METODE PENELITIAN}

Penelitian ini adalah penelitian deskriptif kualitatif.Data diambil dari buku, Intermediate Javanese, yang merupakan buku pelajaran bahasa Jawa untuk penutur bahasa Inggris. Buku ini berisi pelajaran bahasa Jawa baik tentang tata bahasa, pengetahuan tentang budaya Jawa dan contoh-contoh percakapan dalam berbagai konteks situasi. Sebagian contoh percakapan berupa percakapan antara penutur bahasa Inggris yang sedang belajar bahasa Jawa dengan penutur bahasa Jawa asli. Percakapan ini disertai terjemahannya dalam bahasa Inggris yang diletakkan pada bagian akhir dalam buku ini.

Karena penelitian ini berkisar tentang bagaimana strategi kesantunan yang diterapkan dalam buku Intermediate Javanese maka hanya teks yang berupa percakapan yang diambil sebagai data dalam penelitian ini. Penelitian ini adalah penelitian Pragmatik, sebuah studi bahasa yang menyangkut bagaimana bahasa dipakai sesuai konteksnya, sehingga percakapan dianggap sebagai data yang paling tepat.

\section{HASIL DAN PEMBAHASAN}

Untuk memudahkan mengidentifikasi bagaimana strategi kesantunan diterapkan dalam percakapan berbahasa Jawa dan versi terjemahannya dalam bahasa Inggris, sebagian data diambil dari tindak tutuk direktif. Tindak tutur jenis ini dianggap yang paling mengancan muka mitra bicara dibanding jenis tindak tutur lain. Karena itu, tindak tutur ini paling banyak menerapkan strategi kesantunan untuk memperingan tindakan mengancam (FTA) muka mitra bicara.

Berdasarkan seluruh teks dalam buku intermediate Javanese, diambil tiga teks percakapan yang berjudul "Teka ing Lapangan Terbang Meguwo," "Pardi Menyang Ngomahe Pamane," dan "OmongOmongan antara Slamet Karo Parto" serta terjemahannya, "Arrival at Meguwo Airport, Yogyakarta", "Pardi visits His Uncle," dan "Conversation between Slamet Nad Parto". Dari ketiga percakapan berbahasa Jawa dan terjemahannya ini ditemukan dua puluh ujaran yang mengandung strategi kesantunan. Berdasarkan kategori strategi kesantunan yang diterapkan pada kedua puluh ujaran ini didapat sebaran sebagai berikut: 
Strategi Kesantunan

\begin{tabular}{llc}
\hline No & StrategiKesantunan & Jumlah \\
\hline 1 & Bald on Record & 6 \\
2 & KesantunanPositif & 7 \\
3 & KesantunanNegatif & 8 \\
4 & Off Record & 0 \\
\hline
\end{tabular}

Dari keempat strategi kesantunan yang diterapkan, ditemukan kesantunan negatif sebagai kesantunan yang paling banyak diterapkan pada percakapan dalam ketiga konteksnya. Kesantunan ini banyak diterapkan pada percakapan antara $\mathrm{Mr}$ Ward, tamu dari Amerika dengan petugas di bandara Meguwo dan Dr Sukarso. Strategi ini wajar sekali diterapkan antara dua orang yang belum dikenal karena pada dasarnya strategi kesantunan negatif adalah strategi kesantunan dengan memberikan jarak sosial, menempatkan mitra bicara pada posisi yang lebih tinggi. Strategi kesantunan inilah yang dianggap sebagai kesantunan dalam kehidupan sehari-hari.

Strategi kesantunan berikutnya yang banyak diterapkan pada percakapan adalah strategi kesantunan positif. Ada tujuh data ujaran yang menerapkan strategi kesantunan ini. Strategi ini dipakai pada percakapan antara tokoh paman dan keponakannya, Pardi pada teks yang berjudul "Pardi Menyang Ngomahe Pamane". Strategi kesantunan positif adalah strategi kesantunan dengan menenpatkan mitra bicara sebagai bagian kelompok dari si pembicara. Strategi kesantunan ini mengajak mita bicara ke dalam jarak sosial yang dekat. Jadi bisa diduga bahwa meskipun dalam percakapan ini hubungan antara dua mitra bicara ini berjarak sosial tapi si pembicara dalam hal ini paman berusaha untuk mendekatkan jarak sosial lewat strategi kesantunan positif. Strategi kesantunan ini ternyata diterapka juga pada percakapan antara dua teman akrab pada percakapan dengan judul "Omong-Omongan antara Slamet karo Parto". Ini menunjukan bahwa strategi percakapan ini juga diterapkan pada teman dekat.

Strategi kesantunan yang ketiga adalah strategi kesantuna bald on record. Strategi kesantunan ini menunjukan sebuag strategi komunikasi dengan menganggap mitra tutur sebagai pihak yang tidak punya jarak sosial dengan si pembicara. Pada percakapan pada contoh penelitian ini strategi ini banyak diterapkan pada percakapan antara Slamet dan Parto pada teks percakapan dengan judul "Omong-Omongan antara Slamet karo Parto". Hal ini mudah dipahami karena pada teks tersebut hubungan antara Slamet dan Parto adalah hubungan teman dekat, sehingga strategi ini paling memungkinkan diterapkan pada percakapan mereka. Sayang sekali strategi kesantunan off record tidak ditemukan pada teks percakapan dalam buku Intermediate Javanese ini. Secara umum sebaran strategi kesantunan yang diterapkan adalah sebagai berikut: 


\begin{tabular}{|c|c|c|c|c|}
\hline NO & BSU & PS & BSA & PS \\
\hline 1 & $\begin{array}{l}\text { Cobi punika wonten Pak Dokter Sukarso. Kula } \\
\text { suwunaken nunutan njih? }\end{array}$ & 2 & $\begin{array}{l}\text { Here's DrSukarso: let me } \\
\text { just ask him for a ride for } \\
\text { you. }\end{array}$ & 2 \\
\hline 2 & $\begin{array}{l}\text { 0, mekaten. Pak Dokter, punika wonten priyantun } \\
\text { Amerika, Tuan Ward, rawuhsaking Djakarta bade } \\
\text { dateng hotel Garuda, punapa saged nderek? }\end{array}$ & 3 & $\begin{array}{l}\text { Oh, I see. Doctor, there is } \\
\text { an American here, Mr } \\
\text { Ward, who has come from } \\
\text { Djakarta and wants to go } \\
\text { to the hotel Garuda; can } \\
\text { he come along with you? }\end{array}$ & 3 \\
\hline 3 & Kula punapapa pareng nderek teng kota? & 3 & $\begin{array}{l}\text { May I ride into the city } \\
\text { with you? }\end{array}$ & 3 \\
\hline 4 & Barang panjenengan punapa sampun panjenengan asta? & 3 & $\begin{array}{l}\text { Have you got your } \\
\text { luggage? }\end{array}$ & 3 \\
\hline 5 & $\begin{array}{l}\text { Mangga kula tepanganken, Tuan Ward, punika dokter } \\
\text { Sokarso }\end{array}$ & 2 & $\begin{array}{l}\text { I 'll introduce you, } \mathrm{Mr} \\
\text { Ward, punikaDrsukarso. }\end{array}$ & 2 \\
\hline 6 & Sampun, maturnuwun sanget, kepareng nderek. & 3 & $\begin{array}{l}\text { Goodbye, thank you for } \\
\text { the ride. }\end{array}$ & 3 \\
\hline 7 & Menawi kersa mangke saged sesarengan. & 2 & $\begin{array}{l}\text { You can join me if you'd } \\
\text { like. }\end{array}$ & 2 \\
\hline 8 & $\begin{array}{l}\text { Panjenengan kula aturi rawuh ing kantor kula } \\
\text { kemawon. }\end{array}$ & 3 & $\begin{array}{l}\text { Can you come to my } \\
\text { office? }\end{array}$ & 3 \\
\hline 9 & Kene, mlebua, Di. & 2,3 & Come on in, Di. & 2,3 \\
\hline 10 & Kepenakna lungguhmu, Di. & 1,3 & $\begin{array}{l}\text { Make yourself at home, } \\
\text { Di. }\end{array}$ & 1,3 \\
\hline 11 & Mulane sinaumu sing mempengya Di. & 2 & $\begin{array}{l}\text { So, you you'd better study } \\
\text { as hard as you can, Di. }\end{array}$ & 2 \\
\hline 12 & Kok enggal enggal bali, mbok ngenteni Bulikmu disik. & 3 & $\begin{array}{l}\text { Leaving so soon? Won't } \\
\text { you wait for your aunt? }\end{array}$ & 3 \\
\hline 13 & Ayo ta mlebuadisik. & 1 & Come on in. & 1 \\
\hline 14 & Yabener, mungwae kana ta endangadusa. & 1 & But please take your bath. & 2 \\
\hline 15 & $\begin{array}{l}\text { Yawisayo, pit pitan nglencer disik, nek wis banjur } \\
\text { ndeleng gambar hidup. Cocok? }\end{array}$ & 2 & $\begin{array}{l}\text { All right, let's go for a } \\
\text { bike ride first, than see a } \\
\text { movie after that. Okay? }\end{array}$ & 2 \\
\hline 16 & $\begin{array}{l}\text { Nek dandano rausah kaya putri lho. Limangmenit } \\
\text { rampung. }\end{array}$ & 1 & $\begin{array}{l}\text { don't take as much time } \\
\text { getting dressed like a girl. } \\
\text { Finish it up in five } \\
\text { minutes! }\end{array}$ & 1 \\
\hline 17 & Wisayo to enggal. & 1 & Come on. Hurry up! & 1 \\
\hline 18 & E, Met! Ayo menggok keneyo. & 2 & $\begin{array}{l}\text { Hey, Met, let's turn in } \\
\text { here. }\end{array}$ & 2 \\
\hline 19 & Gelem kowe tak jak nyeng nggone kancaku? & 3 & $\begin{array}{l}\text { How would you like to } \\
\text { drop in on a friend of } \\
\text { mine. }\end{array}$ & 3 \\
\hline 20 & Yabecik, ayo enggal enggal mengko mundak kasep. & 2 & $\begin{array}{l}\text { All right. Let's hurry, so } \\
\text { we won't be late. }\end{array}$ & 2 \\
\hline
\end{tabular}

Penjelasan tentang bagaimana strategikesantunan yang diterapkan padateks berbahasa Jawa diterjemahkandalambahasa Inggris dalam buku Intermediate Javanese diurutkan berdasar banyaknya strategi ini diterapkan pada percakapan pada buku tersebut. Strategi kesantunan yang paling banyak diterapkan adalah strategi kesantunan negatif sedangkan bald on record adalah jenis strategi kesantunan yang paling sedikit diterapkan. 
Jenis kesantunan ini banyak diterapkan pada teks percakapan yang berjudul "Teka ing Lapangan Terbang Meguwo," dan terjemahannya "Arrival at Meguwo Airport, Yogyakarta", dengan tokohnya Mr Ward, petugas lapangan terbang dan Dr Sukarso. Percakapan ini berlatar belakang antar orang-orang yang tidak saling mengenal di Bandara Meguwo.

\begin{tabular}{ll}
\hline \multicolumn{1}{c}{ BSU } & \multicolumn{1}{c}{ BSA } \\
\hline Kula punapa & May I ride into \\
pareng nderek teng & the city with \\
kita? & you? \\
\hline
\end{tabular}

Percakapan pada data di atas terjadi antara $\mathrm{Mr}$ Ward, seorang tamu dari Amerika kepada Dr Sukarso, seseorang yang baru ditemuinya di bandara. Mr Ward yang tidak berhasil mendapatkan transportasi umum untuk menuju hotel Garuda tempatnya tinggal selama di Yogyakarta. Di sini nampak $\mathrm{Mr}$ menggunakan tindak tutur bertanya untuk meminta tumpangan. Bentuk pertanyaan untuk mengungkapkan perintah atau permintaan merupakan salah satu strategi kesantunan negatif yang sangat umum. Bentuk strategi ini menempatkan orang lain sebagai orang yang tidak layak untuk diganggu kenyamanannya. Bentuk pertanyaan untuk mengungkapkan permintaan menempatkan mitra tutur pada posisi yang memungkinkannya untuk menolak dengan mudah.
Pada terjemahannya, tindak tutur meminta ini tetap dipertahankan dalam bentuk pertanyaan sehingga strategi kesantunannyapun tidak berubah. Kesantunan yang diterapkan dalam versi bahasa Jawa tetap dipertahankan dalam bahasa Inggris karena jenis tindak tutur lokusinya tidak berubah antara versi bahasa Jawa dan bahasa Inggris.

\section{Strategi Kesantunan Positif.}

Startegi kesantunan positif pada teks percakapan dalam buku Intermediate Javanese ini sebagian besar diterapkan pada dua orang yang saling mengenal tapi tetap ada jarak ssosial diantaranya. Dalam hal ini, percakapan itu diwakili oleh tokoh Pardi dan pamannya.

Strategi kesantunan positif dalam ujaran di atas ditandai dengan pemakaian nama panggilan. Strategi kesantunan positif memang dilakukan dengan cara mengecilkan jarak sosial antara si pembicara dengan mitra bicaranya. Strategi ini juga antara lain beurasaha untuk menunjukan sikap solidaritas. Pada bentuk terjemahannya, strategi kesantunan positif ini tetap dipertahankan. Penggunaan nama panggilan dipertahankan dalam teks terjemahan sehingga strategi kesantunan tetap sepadan.

Strategi kesantunan bald on record pada percakapan diwakili oleh percakapan antara Slamet dan Parto dalam teks percakapan yang berjudul "Omongomongan Slamet karo Paryo" 


\begin{tabular}{lll}
\hline \multicolumn{1}{c}{ BSU } & \multicolumn{1}{c}{ BSA } \\
\hline 14 & $\begin{array}{l}\text { Yabener, } \\
\text { mungwae kana ta } \\
\text { endangadusa. }\end{array}$ & But please take \\
your bath.
\end{tabular}

Strategi kesantunan bald on record pada kasus percakapan di atas melibatkan dua orang yang sudah dekat secara jarak sosial. Strategi kesantunan bald on record merupakan penanda bahwa hubungan sosial keduanya dekat.

Pada teks percakapan terjemahan ternyata strategi ini sedikit bergeser dari strategi kesantunan bald on record menjadi strategi kesantunan negatif yang ditandai dengan ekspresi "please"

\section{Penerapan Konsep Kesantunan}

\section{dalam Pembelajaran Penerjemahan}

Seseorang dapat dianggap baik salah satunya karena kesantunannya dalam berucap atau berbahasa dan bertingkah laku. Oleh karena itu penting untuk mengajarkan konsep kesantunan pada mahasiswa Pendidikan Bahasa Inggris UNISRI. Terlebih lagi di budaya Jawa yang dikenal cukup rumit dan unik. Konsep kesantunan dapat dilihat dari penggunaan 'undha usuk' atau tataran bahasa. Terdapat Bahasa Jawa Ngoko, Kromo Madya, dan Kromo Inggil. Sebagai contoh dalam penggunaan kata 'kamu' atau 'anda' dalam Bahasa Inggris kata tersebut diterjemahkan menjadi 'you' meskipun ditujukan bagi orang tua sekalipun. Namun tidak demikian dalam Bahasa Jawa. 'Kamu' dapat diterjemahkan menjadi 'koe' atau 'panjenengan' bisa juga diterjemahkan menjadi 'bapak' atau 'ibu' tergantung pada konteks dengan siapa kita berbicara.

Hasil analisis tentang strategi kesantunan yang diambil dari teks berbahasa Jawa dan terjemahannya dalam Bahasa Inggris di atas dapat digunakan sebagai contoh materi pembelajaran tentang konsep kesantunan dalam kelas Translation. Misalnya ketika berhadapan dengan orang yang baru saja dikenal, maka strategi kesantunan negatif baik diterapkan. Untuk menjaga muka atau 'face' seseorang mahasiswa perlu diberikan contoh strategi kesantunan yang tepat sesuai konteks terutama dalam menerjemahkan teks berbahasa Jawa ke dalam Bahasa Inggris. Mahasiswa dapat mempelajari berbagai contoh strategi kesantunan dari teks dalam buku di atas.

\section{KESIMPULAN}

Ada tiga strategi kesantunan yang diterapkan pada teks percakapan pada buku Intermediate Javanese dan terjemahannya. Strategi kesantunan tersebut adalah: Strategi kesantunan negatif, strategi kesantunan positif dan strategi kesantunan bald on record. Secara umum strategi kesantunan yang diterapkan dalam versi terjemahan sama dengan strategi kesantunan yang diterapkan pada versi bahasa Jawa. Hanya ada sebagian kecil strategi kesantunan yang 
mengalami pergeseran. Konsep kesantunan penting diberikan kepada mahasiswa Pendidikan Bahasa Inggris agar mereka tidak saja menghasilkan terjemahan berkualitas namun juga mampu berbahasa dengan baik dan benar. Materi ini juga bermanfaat untuk pembentukan karakter mahasiswa.

\section{DAFTAR PUSTAKA}

Baker, Mona.(1992). In Other Words. London and Newyork: RoutLedge.

Brown and Levinson. (1987). Politeness; some universals in language usage. United Kingdom: Cambridge University Press

Catford, J. C. (1980). A Linguistik Theory of Translation. London: Oxford University Press.

Gazdar, Gerald. (1979). Pragmatiks, implicature, presupposition, and Logical Form. England: Academic Press.

Hatim, B. and I. Mason. (1997). The Translator as Communicator. London/New York: Routledge.
Spradley, James P. (2006). Metode Etnografi (M.Z. Elizabeth, Trans). Yogayakarta: Tiara Wacana.

Larsen-Freeman,Diane.(2000).Techniques and Principles in Language Teaching. Oxford University Press.

Larson, Mildred A. (1984). Meaning-Based Translation. Lanham: University Press of America.

Leech, Geoffrey. (1983). Principles of Pragmatiks. London: Longman Group Limited.

Moleong, Lexy J.( 2005). Metodologi Penelitian Kualitatif. Bandung : Rosda

Newmark, Peter. (1981). A text Book of Translation. Singapore:Prentice Hall

Nida, Eugene A. (1969). The Theory and Practice of Translation. Den Hag: E.J. Brill.

(1996). context in Translating. Amsterdam : John Benjamins Publishing Co.

Sutopo, H.B. (2006)Metode Penelitian Kualitatif: Dasar Teori dan Terapannya dalamPenelitian. Surakarta: UNS Press.

Yule, George.(1996). Pragmatiks.Newyork: Oxford University Press.

Farewell dan Heimrich. (2006). Pragmatics and Translation. 